Isotopes in tufa recording Eemian seasonal temperature

\title{
Stable isotope record of Eemian seasonal temperature from MIS 5 e tufa stromatolite; Somme Basin, Northern France
}

J. Dabkowski ${ }^{1,2}$, J. Andrews ${ }^{3}$, P. Antoine ${ }^{1}$, and A. Marca-Bell ${ }^{3}$

${ }^{1}$ Laboratoire de Géographie Physique, CNRS - UMR8591, Meudon, France

${ }^{2}$ Département de Préhistoire du Muséum National d'Histoire Naturelle, UMR7194, Paris, France

${ }^{3}$ School of Environmental Sciences, University of East Anglia, Norwich, UK

Received: 31 January 2013 - Accepted: 15 March 2013 - Published: 27 March 2013

Correspondence to: J. Dabkowski (dabkowski@mnhn.fr)

Published by Copernicus Publications on behalf of the European Geosciences Union.

J. Dabkowski et al.

Title Page

Abstract

Introduction

Conclusions

References

Tables

Figures

14

4

Back

Full Screen / Esc

Printer-friendly Version

Interactive Discussion

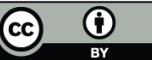




\section{Abstract}

In many modern to sub-fossil deposits tufa formations, very well crystallised deposits called stromatolites are preserved. These are often strongly laminated deposits, the laminae linked to seasonal climatic and environmental variations. Where found in fossil 5 tufas such deposits have huge potential as high resolution archives of Pleistocene climate. One of the first investigations of this type has been performed on a $2.5 \mathrm{~cm}$-radius stromatolite from the Eemian sequence of Caours (Somme Basin, Northern France), where precise observations in thin section have been combined with intra-lamina $\delta^{18} \mathrm{O}$ and $\delta{ }^{13} \mathrm{C}$ analyses. Independent interpretations of petrographical and geochemical data are strongly coherent and demonstrate a clear seasonal signal. Moreover, as $\delta^{18} \mathrm{O}$ is temperature dependent, we have quantified likely maximum water temperature variations between summer and winter at Caours. A small mismatch between the $\delta^{18} \mathrm{O}$ derived temperature values and the typical modern range is observed, which may reflect a real difference between modern and Eemian temperature seasonality. 15 This study supports previous investigations performed on a laminated tufa from central Greece and clearly confirms the potential of tufa stromatolites as records of seasonal climatic information and for the quantification of riverine water temperature variations.

\section{Introduction}

The calcareous tufa deposit of Caours covers $>10000 \mathrm{~m}^{2}$ and is up to $3.5 \mathrm{~m}$ thick; it overlies lower terrace fluvial deposits of the Scardon, a Somme River tributary (Northern France; $50^{\circ} 07^{\prime} \mathrm{N}, 01^{\circ} 52^{\prime} \mathrm{E}$; Fig. 1a). This complex tufa sequence is assigned to the Eemian Interglacial (MIS 5e) based on its location in the Somme River terraces system, paleontological data, and a chronology from $10 \mathrm{U} / \mathrm{Th}$-TIMS on calcite (average of $124 \pm 4 \mathrm{kyr} B P$ ), combined with OSL on fluvial quartz, and TL on archaeological burnt 25 flint).

\section{CPD}

$9,1657-1674,2013$

Isotopes in tufa recording Eemian seasonal temperature

J. Dabkowski et al.

\section{Title Page}

\section{Full Screen / Esc}

Printer-friendly Version

Interactive Discussion 
Since 2005, archaeological excavations of a Middle Palaeolithic site preserved at the base of the tufa formation (dir. J. L. Locht, INRAP Picardie) have provided excellent stratigraphical profiles (up to $20 \mathrm{~m}$ long). They support multidisciplinary studies mainly based on large mammal remains and malacological investigations that allowed 5 evidencing the Eemian climatic optimum at the base of the sequence (Antoine et al., 2006, 2007).

Very well crystallised deposits including original tubular stromatolites with concentric laminations are locally abundant and very-well preserved within the tufa sequence (Antoine et al., 2006). Tufa stromatolites often preserve clear laminations thought to 10 be linked to seasonal climatic and environmental conditions (Chafetz and Folk, 1984; Freytet and Plet, 1991; Freytet and Verrecchia, 1998); these laminae have great potential for very high resolution study of Pleistocene climate (Andrews and Brasier, 2005). We present here one of the first investigations of this type (Brasier et al., 2010) combining precise petrographical observations with high resolution stable isotope data.

\section{Materials and methods}

We analysed a $2.5 \mathrm{~cm}$-radius stromatolite from Caours sector S2 (excavated in 2005), a tubular facies encrusted around plant stems (1-2 mm in diameter), which overlays tufaceous and detrital fluvial deposits of a localised channel (Fig. 1b and c). In hand specimen, polished cross-sections show alternation of clear translucent and darker 20 porous laminae (Fig. 2).

Petrographic observations on non-impregnated thin sections allowed determination of the cyanobacterial/algal taxa involved in the stromatolite construction, based on the fossil freshwater taxa descriptions of Freytet $(1997,1998)$ and can provide palaeoecological information based on comparison between fossil and modern taxa (Dabkowski et al., 2010). Boundaries between laminae were defined precisely and laminae sampled for geochemistry were screened for diagenetic alteration.

\section{CPD}

$9,1657-1674,2013$

Isotopes in tufa recording Eemian seasonal temperature

J. Dabkowski et al.

\section{Title Page}

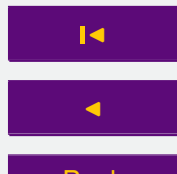
$\Delta$

\section{Full Screen / Esc}

Printer-friendly Version

Interactive Discussion 
Geochemical analyses focused on the stable isotopes of oxygen and carbon $\left(\delta^{18} \mathrm{O}\right.$ and $\delta^{13} \mathrm{C}$ ). Two $6 \mathrm{~mm}$-long transects (Str-HR, 33 samples and Str-HR2, 36 samples; Fig. 3) were sampled parallel to the growth direction of the stromatolite, i.e. normal to laminae, using a Micromill. Isotopic analyses were made on $\mathrm{CO}_{2}$ derived from $5100 \pm 10 \mu \mathrm{g}$ carbonate material reacted with anhydrous $\mathrm{H}_{3} \mathrm{PO}_{4}$ at $90^{\circ} \mathrm{C}$ in a common acid bath automated preparation system online with a Europa SIRA mass spectrometer. Repeated analyses of the laboratory standard $(n=75)$ gave a $2 \sigma$ precision of $\pm 0.29 \%$ o for carbon and $\pm 0.09 \%$ o for oxygen.

\section{Results}

\subsection{Petrography}

No detrital material was seen in thin section and evidence of organic matter is sparse. The stromatolite is wholly composed of micritic to sparitic calcite crystals. Four microfacies were determined, labelled I to IV (Fig. 2). Their alternation corresponds to the translucent and darker porous laminae seen in hand specimen.

15 Microfacies I and II are best represented (Fig. 2), the first corresponding to continuous sparitic laminae with crystal long axes of a few hundred microns to millimetre dimensions. In some cases, internal laminae are present, underlain by very thin organic horizons (Fig. 2). Microfacies II is of micritic to microsparitic composition, typically a few tens to hundreds of microns thick with continuous wavy to planar internal laminae

20 (Fig. 2). Both in Microfacies I and II, cyanobacterial/algal filaments are not clearly visible, although where present and better preserved in Microfacies I, filaments are more or less erect, well-spaced, parallel to the growth direction, and forming fascicules of various shapes.

Microfacies III corresponds to the very porous laminae seen in hand specimen. 25 Sparitic crystals including filaments and fascicules, similar to those in Microfacies I, form discontinuous, vuggy and disorganised laminae (Fig. 2).

\section{CPD}

9, 1657-1674, 2013

Isotopes in tufa recording Eemian seasonal temperature

J. Dabkowski et al.

\section{Title Page}

Abstract

Introduction

Conclusions

Tables

References

Figures

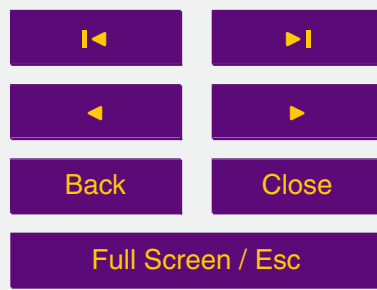

Printer-friendly Version

Interactive Discussion 
Microfacies IV is a clotty micrite lacking internal lamination or cyanobacterial/algal filament structure (Fig. 2). This microfacies forms a $0.5 \mathrm{~cm}$ thick lamina, interrupted by two tens of microns thick sparitic layers (red arrows on Fig. 2); microsparitic crystals are also observed around the edges of vugs. This microsparite is the only clear evidence 5 of neomorphic alteration and the mass of calcite of this type is small. No other clearly diagnostic diagenetic fabrics were observed.

The boundaries between laminae formed on these different microfacies are sharp and easily observed (Fig. 2): they are drawn precisely on Fig. 3, as are the stable isotope data.

\subsection{Stable isotopes}

The stable isotope data are summarised in Table 1 and data sets are associated with this paper as Supplementary Material. $\delta^{18} \mathrm{O}$ values range between -6.3 and $-4.2 \%$ (mean value: $-5.2 \pm 0.09 \%, n=63$; Table 1 ) and $\delta^{13} \mathrm{C}$ values range between -11.2 and $-7.5 \%$ (mean values: $-10.0 \pm 0.3 \%, n=63$; Table 1 ). These $\delta^{18} \mathrm{O}$ and ${ }_{15} \delta^{13} \mathrm{C}$ ranges are consistent with those from late Quaternary temperate tufas from NW Europe where continentality and aridity/evaporation effects are small (Andrews, 2006).

In Fig. 3, the isotope data are plotted against position in the Str-HR 2 sample transect, showing the precise relationship with microfacies alternations. The lowest $\delta^{18} \mathrm{O}$ values (both absolute and relative values within the profile) derive from sparitic microfacies I, whereas other microfacies produced broadly less negative values, but without distinction between microfacies. The two thin microsparitic horizons in microfacies IV samples (Str-HR 2; Fig. 3) are also associated with decreases in the $\delta^{18} \mathrm{O}$ signal. The $\delta^{13} \mathrm{C}$ profile is smoother but with a shape broadly similar to the $\delta^{18} \mathrm{O}$ data: there is a statistically significant positive correlation between $\delta^{18} \mathrm{O}$ and $\delta^{13} \mathrm{C}$ in both Str-HR and

\section{CPD}

$9,1657-1674,2013$

Isotopes in tufa recording Eemian seasonal temperature

J. Dabkowski et al.

\section{Title Page}

Abstract

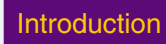

Conclusions

Tables References Figures
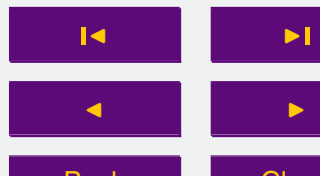

$>$

Back

Close

Printer-friendly Version

Interactive Discussion 


\section{Interpretation and discussion}

\subsection{Seasonal control of lamina microfacies}

When stromatolite growth stops or slows down dramatically it might be expected that detritus would accumulate on the growth surface, subsequently encrusted by the next 5 phase of stromatolite growth. The low organic matter content and lack of detrital layers are thus interpreted to represent nearly continuous and fast calcite precipitation, although the sharp transitions between laminae could result from short hiatuses.

The arrangement of cyanobacterial/algal filaments and fascicules in Microfacies IIII, is diagnostic of the fossil taxa Broutinella arvenensis (Freytet, 1998). The holotype description (Freytet, 1998) is very similar to the material described here, particularly the features in Microfacies I: $B$. arvenensis builds variably micritic to sparitic fabrics including continuous wavy to planar internal laminations, often underlain by thin organic horizons (Freytet, 1998). Microfacies IV shows no clear cyanobacterial/algal structure: it is interpreted here as a microbial fabric but is not assigned to specific taxa.

There is little doubt that much of the Caours tufa stromatolite was built by $B$. arvenensis and this morphotaxa is thought to represent the modern Cyanobaterial genera Phormidium and Schizothrix (Freytet, 1998). These are known to constitute an algal biocenose where one is predominant during spring and the other during autumn, generating alternating laminae (Freytet, 1992; Freytet and Plet, 1996). It is thus inferred that the formation of the Caours tufa stromatolite laminae was seasonally controlled.

A clear feature of the microfacies pattern (Fig. 2) is the rhythmic presence of sparitic Microfacies I. While some authors have considered such fabrics diagenetic (Janssen et al., 1999; Janssen, 2000), there are many others who view such fabrics as primary; moreover in Microfacies I the clear preservation of cyanobacterial filaments ar25 gue against a diagenetic origin. Indeed the presence of expanded fascicules suggests growth conditions favourable for cyanobacterial colonies.

\section{CPD}

$9,1657-1674,2013$

Isotopes in tufa recording Eemian seasonal temperature

J. Dabkowski et al.

\section{Title Page}

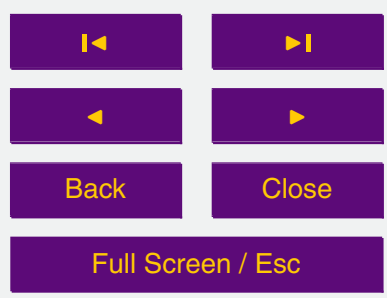

Printer-friendly Version

Interactive Discussion 
In laminated European tufas, alternation of dense micritic laminae and more porous laminae containing erect cyanobacterial/algal filaments have been shown to correspond to winter and summer conditions respectively (Freytet, 1990; Freytet and Plet, 1996; Janssen et al., 1999). We thus propose that Microfacies I calcite crystals grew in 5 summer under strong solar illumination and warm temperatures, whereas the other microfacies represent more limited cyanobacterial and microbial growth under less favourable winter conditions.

In our sampling series (Str-HR and Str-HR 2) seven Microfacies I laminae represent summer conditions (shown in red, Fig. 3), including the two continuous sparitic layers 10 that interrupt Microfacies IV. These alternate with six layers corresponding to winter conditions (shown in blue, Fig. 3). On this basis at least six annual cycles are covered by our transects. We find no evidence of pervasive diagenetic alteration, except, possibly, the small amounts of microspar around vug margins in Microfacies IV; thus we infer that the calcite and its attendant geochemical data, are records of seasonal changes 15

\subsection{Stable isotope record}

\subsubsection{Stable oxygen isotopes}

Assuming near isotopic equilibrium between calcite and its depositing water, as demonstrated for recent NW European tufa deposits (Andrews et al., 1997; Garnett et al., 20 2004), variations in tufa $\delta{ }^{18} \mathrm{O}$ are likely to have been caused mainly by (1) change in the water temperature at the time of calcite precipitation and/or, (2) variation in the isotopic composition of the water from which tufa calcite precipitates. The first mechanism is described by Craig's thermodynamic equation where a $1^{\circ} \mathrm{C}$ increase in water temperature results in a $-0.24 \%$ change in $\delta^{18} \mathrm{O}$ of the precipitating calcite (Craig, 1965). Changes in the isotopic composition of the tufa precipitating water (mechanism 2 above) is caused by changes in the mean annual isotopic composition of the meteoric water that recharges groundwater-fed springs (Clark and Fritz, 1997; Darling,

\section{CPD}

$9,1657-1674,2013$

Isotopes in tufa recording Eemian seasonal temperature

J. Dabkowski et al.

\section{Title Page}

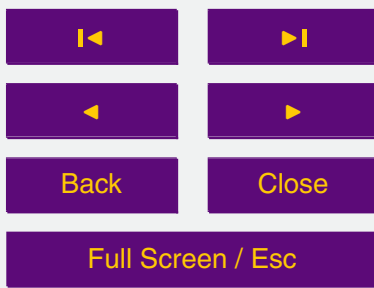

Printer-friendly Version

Interactive Discussion 
2004). However, most spring waters are fed from aquifers where there has been significant mixing and homogenization of the recharging waters (Darling, 2004). It is thus unlikely that any systematic variation in water isotopic composition (mechanism 2) would be seen in a sampling series taken at sub-annual resolution as is the case here.

$5 \quad$ At sub annual to annual resolution, increasing $\delta^{18} \mathrm{O}$ in tufa calcite is much more likely to be caused by decreasing water temperature (Andrews, 2006; Matsuoka et al., 2001; O'Brien et al., 2006; Hori et al., 2009) and vice versa.

The lowest $\delta^{18} \mathrm{O}$ values (warmest water temperatures) are clearly associated with the "summer-laminae" of Microfacies I (Fig. 3). The other microfacies correspond to o higher $\delta^{18} \mathrm{O}$ values which we assigned broadly to cooler "winter" conditions (microfacies II, III and IV). Our independent interpretations of petrographical and stable isotope data are thus strongly coherent and demonstrate the clear potential to identify seasonal palaeoclimatic signals in ancient tufa deposits.

15 Using Craig's equation (1965), we can calculate the maximum change of water temperature recorded in this tufa stromatolite. $\delta^{18} \mathrm{O}$ values range between -6.3 and $-4.2 \pm 0.1 \%$ o (i.e. $2.2 \pm 0.1 \%$ of change), which equates to a maximum water temperature variation of $9.0 \pm 0.3^{\circ} \mathrm{C}$ between winter and summer. Present water temperatures of the Scardon measured at Abbeville, a few kilometres downstream from Caours, between 1970 and 2010 (station 1410000; data sources: AEAP/DIREN/CSP/Banque du Bassin Artois-Picardie; www.eau-artois-picardie.fr) record a typical range of c. $12^{\circ} \mathrm{C}$ between summer (April to September) and winter (October to March).

This c. $3^{\circ} \mathrm{C}$ difference, between seasonal temperature variations calculated from the Caours stromatolite $\delta^{18} \mathrm{O}$ values and the modern Scardon typical range, could be

1. The sharp boundaries observed in thin section between summer and winter laminae result from hiatuses in stromatolite growth, and thus a possible non-record of winter and/or summer maximum temperatures. An earlier study of MIS 5 Phormidium tufa stromatolites from central Greece (Brasier et al., 2010) showed

CPD

$9,1657-1674,2013$

Isotopes in tufa recording Eemian seasonal temperature

J. Dabkowski et al.

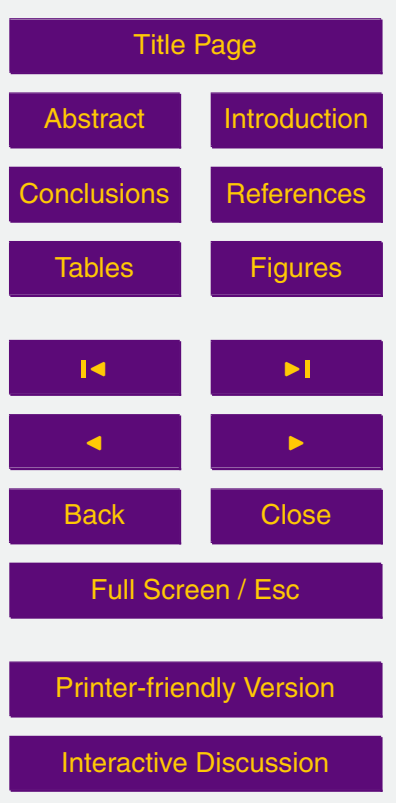

Interactive Discussion 
a clear seasonal record in $\delta^{18} \mathrm{O}$, temperature and tufa fabric, rather similar to the present study (Fig. 4). These authors explained lower calculated $\delta^{18} \mathrm{O}$ temperature ranges, relative to modern water temperature seasonal ranges, as resulting from summer and winter hiatuses. These hiatuses were clearly identified by the

shape of the $\delta^{18} \mathrm{O}$ and $\delta^{13} \mathrm{C}$ curves which showed abrupt changes at lamina boundaries (Fig. 4). However, abrupt changes are not present in the Caours stromatolite record described here; rather the $\delta^{18} \mathrm{O}$ curve appears relatively smooth, lamina boundaries being synchronous with decreases from high to low $\delta^{18} \mathrm{O}$ values and vice versa. In fact possible hiatuses in the Caours stromatolite seem to correspond to intermediate and not to "extreme" conditions, with maximum and minimum temperatures recorded within the laminae.

2. In Caours sector S2, the tufa formation is mainly composed of massive white to light grey units with little detrital content, prograding parallel to the slope. Moreover, channels ( 0.5 to $1 \mathrm{~m}$ width) with oncolithic infilling are well preserved in the sequence, running from the base of the slope to the palaeo Scardon valley (Antoine et al., 2006). This structure clearly shows proximity of springs on the slope, which fed streams and pools. Water precipitating this tufa may thus have been a mixture of palaeo-Scardon waters and spring waters with a nearly constant temperature, whereas modern temperatures have been measured in the Scardon main stream. Input of groundwater could thus explain the smaller temperature range recorded in the Caours stromatolite.

3. Finally, the temperature range differences between modern and Eemian seasonality may simply be real. Considering the shortness of the present record (c. $6 \mathrm{yr}$ ) and the lack of independent Eemian data for comparison, we are unable at present to prove or disprove this possibility without further investigation.

\section{CPD}

$9,1657-1674,2013$

Isotopes in tufa recording Eemian seasonal temperature

J. Dabkowski et al.

\section{Title Page}

Abstract

Introduction

Conclusions

Tables

References

Figures

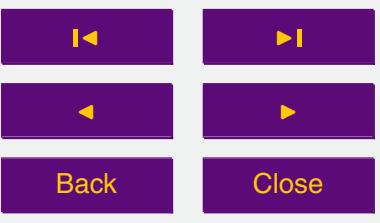

Full Screen / Esc

Printer-friendly Version

Interactive Discussion 


\subsubsection{Stable carbon isotopes}

The $\delta^{13} \mathrm{C}$ values in the tufa as a whole are typical of a modern vegetated NW European river valleys (Andrews, 2006); however, the high resolution record is neither simple or predictable at petrographic boundaries or with $\delta^{18} \mathrm{O}$, even though the statistically 5 significant co-variation between $\delta^{18} \mathrm{O}$ and $\delta^{13} \mathrm{C}$ appears to hint at some co-control on the isotopic composition of the tufa calcites, as observed in some other high-resolution studies of modern and fossil laminated tufa (Matsuoka et al., 2001; O'Brien et al., 2006).

\section{Wider discussion and conclusions}

10 This study of a stromatolite from Caours is one of the first investigations combining precise petrographical observations with high resolution stable isotope data. We demonstrate here that both detailed petrography and geochemistry must be together to interpret such high-resolution record and have confidence in the interpretation of the seasonal isotopic signal.

15 We demonstrate that high resolution environmental/climatic information is recorded (1) in the alternating lamina facies and (2) in the correlated calcite stable isotope variations. This confirms the potential of tufa stromatolites as records of seasonal modifications and for the quantification of riverine water temperature variations.

Comparison of results from this Eemian stromatolite with those from a MIS 5 laminated tufa in central Greece (Brasier et al., 2010; Fig. 4) illustrates that the temporal relationship between lamina microfacies/boundaries and isotope variations are very important. In Northern France, possible hiatuses in stromatolite fabrics appear to correspond to "mid-seasonal", non-extreme conditions whereas in Greek dry summer and cold winter conditions, sharp lamina boundaries correspond with clear discontinuities 25 in isotope profiles indicating non-deposition and truncation of the temperature record. The differences between the French and Greek high resolution records are explained

\section{CPD}

9, 1657-1674, 2013

Isotopes in tufa recording Eemian seasonal temperature

J. Dabkowski et al.

\section{Title Page}

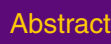

Introduction

Conclusions

Tables References Figures

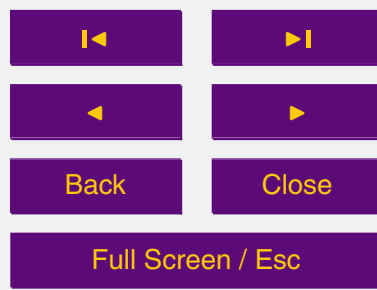

Printer-friendly Version

Interactive Discussion 
because Mediterranean climatic zones (Greece) experience "extreme" seasonality in terms of winter recharge and summer aridity, which are not feature of more oceanic (NW France) climatic zones.

These French and Greek studies suggest strongly that other Eemian European sites 5 with well-crystallised laminated tufa may be used extend our understanding of ancient interglacial climate and seasonality; older interglacial tufas, such as those of MIS 11 may also prove worth investigation. Larger stromatolites are already available from Caours and their high-resolution analyse will allow covering more significant periods of time of a few decades.

10 Supplementary material related to this article is available online at: http://www.clim-past-discuss.net/9/1657/2013/cpd-9-1657-2013-supplement. pdf.

Acknowledgements. The first author thanks Simon Puaud for his help in making thin sections at the Département de Préhistoire of the Muséum National d'Histoire Naturelle (Paris, France). 15 Paul Dennis is thanked for his help and support in the UEA stable isotope laboratory. We warmly thank Alexander Brasier for providing Zemeno full data.

\section{References}

Andrews, J. E.: Paleoclimatic records from stable isotopes in riverine tufas: Synthesis and review, Earth-Sci. Rev., 17, 85-104, 2006.

20 Andrews, J. E. and Brasier, A. T.: Seasonal records of climatic change in annually laminated tufas: short review and future prospects, J Quaternary Sci., 20, 411-421, 2005.

Andrews, J. E., Riding, R., and Dennis, P. F.: The stable isotope record of environmental and climatic signals in modern terrestrial microbial carbonates from Europe, Palaeogeogr. Palaeocl., 129, 171-189, 1997.

\section{CPD}

9, 1657-1674, 2013

Isotopes in tufa recording Eemian seasonal temperature

J. Dabkowski et al.

\section{Title Page}

\section{Full Screen / Esc}

Printer-friendly Version

Interactive Discussion 
Antoine, P., Limondin-Lozouet, N., Auguste, P., Locht, J. L., Ghaleb, B., Reyss, J. L., Escudé, E., Carbonel, P., Mercier, N., Bahain, J. J., Falguères, C., and Voinchet, P.: Le tuf de Caours (Somme, France): mise en évidence d'une séquence éemienne et d'un site paléolithique associé, Quaternaire, 17, 281-320, 2006.

5 Antoine, P., Limondin Lozouet, N., Chaussé, C., Lautridou, J.-P., Pastre, J.-F, Auguste, P., Bahain, J.-J., Falguères C., and Ghaleb, B.: Pleistocene fluvial terraces from northern France (Seine, Yonne, Somme): synthesis, and new results from interglacial deposits, Quaternary Sci. Rev., 26, 2701-2723, 2007.

Brasier, A. T., Andrews, J. E., Marca-Bell, A. D., and Dennis, P. F.: Depositional continuity of seasonally laminated tufas: Implications for $\delta^{18} \mathrm{O}$ based palaeotemperatures, Global Planet. Change, 71, 160-167, 2010.

Chafetz, H. S. and Folk, R. L.: Travertines: depositional morphology and the bacterially constructed constituents, J. Sediment. Petrol., 54, 289-316, 1984.

Clark, I. D. and Fritz, P.: Environmental isotopes in hydrogeology, Lewis, Boca Raton, 1997.

Craig, $\mathrm{H}$.: The measurement of oxygen isotope palaeotemperatures, in: Stable Isotopes in Oceanographic Studies and Palaeotemperatures, edited by: Tongiorgi, E., Consiglio Nazionale Delle Ricerche, Laboratorio di Geologia Nucleare, Pisa, 161-182, 1965.

Dabkowski, J., Antoine, P., Limondin-Lozouet, N., Chaussé, C., and Carbonel, P.: Les microfaciès du tuf calcaire éemien (SIM $5 e$ ) de Caours (Somme, France): éléments d'analyse

20 paléoéocologique du dernier interglaciaire, Quaternaire, 21, 127-137, 2010.

Darling, W. G.: Hydrological factors in the interpretation of stable isotopic proxy data present and past: a European perspective, Quaternary Sci. Rev., 23, 743-770, 2004.

Freytet, P.: Contribution à l'étude des tufs calcaires (édifices stromatolithiques) du bassin de Paris, Les organismes constructeurs, aspects microscopiques, Bulletin du Centre de

25 Géomorphologie de Caen, 38, 35-53, 1990.

Freytet, P.: Les cristallisations de calcite associées à des restes de végétaux (algues, feuilles) en milieu fluviatile et lacustre, actuel et ancien (tufs et travertins), B. Soc. Bot. Fr., 139, 69-74, 1992.

Freytet, P.: Non marine Permian to Holocene algae from France and adjacent country, Part 1, Ann. Paleontol., 83, 289-332, 1997.

Freytet, P.: Non marine Permian to Holocene algae from France and adjacent country, Part 2, Ann. Paleontol., 84, 3-51, 1998.

\section{CPD}

9, 1657-1674, 2013

\section{Isotopes in tufa recording Eemian seasonal temperature}

J. Dabkowski et al.

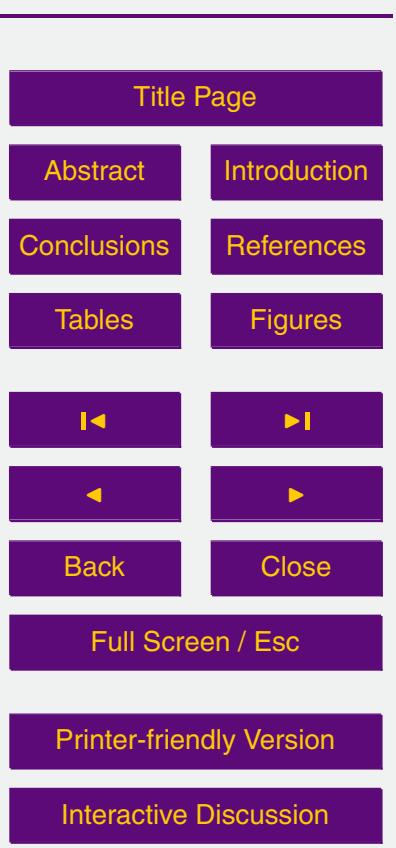


Freytet, P. and Plet, A.: Les formations stromatolitiques (tufs calcaires) récentes de la région de Tournus (Saône-et-Loire), Geobios-Lyon, 24, 123-139, 1991.

Freytet, P. and Plet, A.: Modern freshwater microbial carbonates: the Phormidium stromatolithes (tufa-travertine) of Southeastern Burgundy (Paris Basin, France), Facies, 34, 219238, 1996.

Freytet, P. and Verrecchia, E.: Freshwater organisms that build stromatolites: a synopsis of biocrystallization by prokariotic algae, Sedimentology, 45, 535-563, 1998.

Garnett, E. R., Andrews, J. E., Preece, R. C., and Dennis, P. F.: Climatic chance recorded by stable isotopes and trace elements in a British Holocene tufa, J. Quaternary Sci., 19, 251262, 2004.

Hori, M., Kawai, T., Matsuoka, J., and Kano, A.: Intra-annual perturbations of stable isotopes in tufas: Effects of hydrological processes, Geochim. Cosmochim. Acta, 73, 1684-1695, 2009.

Janssen, A.: Petrography and geochemistry of active and fossil tufa deposits from Belgium, Katholieke Universiteit, Leuven, 2000.

Janssen, A., Swennen, R., Podoor, N., and Keppens, E.: Biological and diagenetic influence in recent and fossil tufa deposits from Belgium, Sediment Geol., 126, 75-95, 1999.

Matsuoka, J., Kano, A., Oba, T., Wanatabe, T., Sakai, S., and Steto, K.: Seasonal variation of stable isotopic compositions recorded in a laminated tufa, SW Japan, Earth Planet. Sc. Lett., 192, 31-44, 2001.

20 O'Brien, G. R., Kaufman, D. S., Sharp, W. D., Atudorei, V., Parnell, R. A., and Crossey, L. J.: Oxygen isotope composition of annually banded modern and mid-Holocene travertine and evidence of paleomonsoon floods, Grand Canyon, Arizona, USA, Quaternary Res, 65, 366379, 2006.

\section{CPD}

9, 1657-1674, 2013

Isotopes in tufa recording Eemian seasonal temperature

J. Dabkowski et al.

\section{Title Page}

Abstract

Introduction

Conclusions

Tables

References

Figures

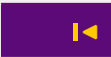

14

4

Back

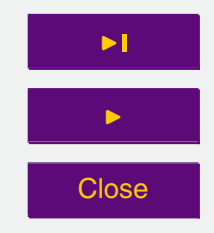

Full Screen / Esc

Printer-friendly Version

Interactive Discussion 
Table 1. High resolution data summaries from Str-HR and Str-HR 2 sampling series of Caours stromatolite.

\begin{tabular}{lrr}
\hline & $\delta^{18} \mathrm{O}$ & $\delta^{13} \mathrm{C}$ \\
& $(\% \circ \mathrm{V}-\mathrm{PDB})$ & $(\% \circ \mathrm{V}-\mathrm{PDB})$ \\
$n=63$ & $n=63$ \\
\hline Minimum & -6.35 & -11.2 \\
Maximum & -4.18 & -7.5 \\
Mean value & -5.18 & -10.0 \\
Confidence interval & \pm 0.09 & \pm 0.3 \\
Standard deviation & 0.51 & 0.7 \\
\hline
\end{tabular}

9, 1657-1674, 2013

\section{Isotopes in tufa recording Eemian seasonal temperature}

J. Dabkowski et al.

\section{Title Page}

Abstract

Introduction

Conclusions

References

Tables

Figures

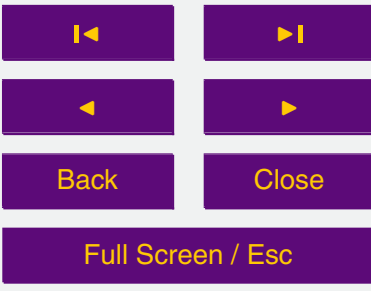

Printer-friendly Version

Interactive Discussion 


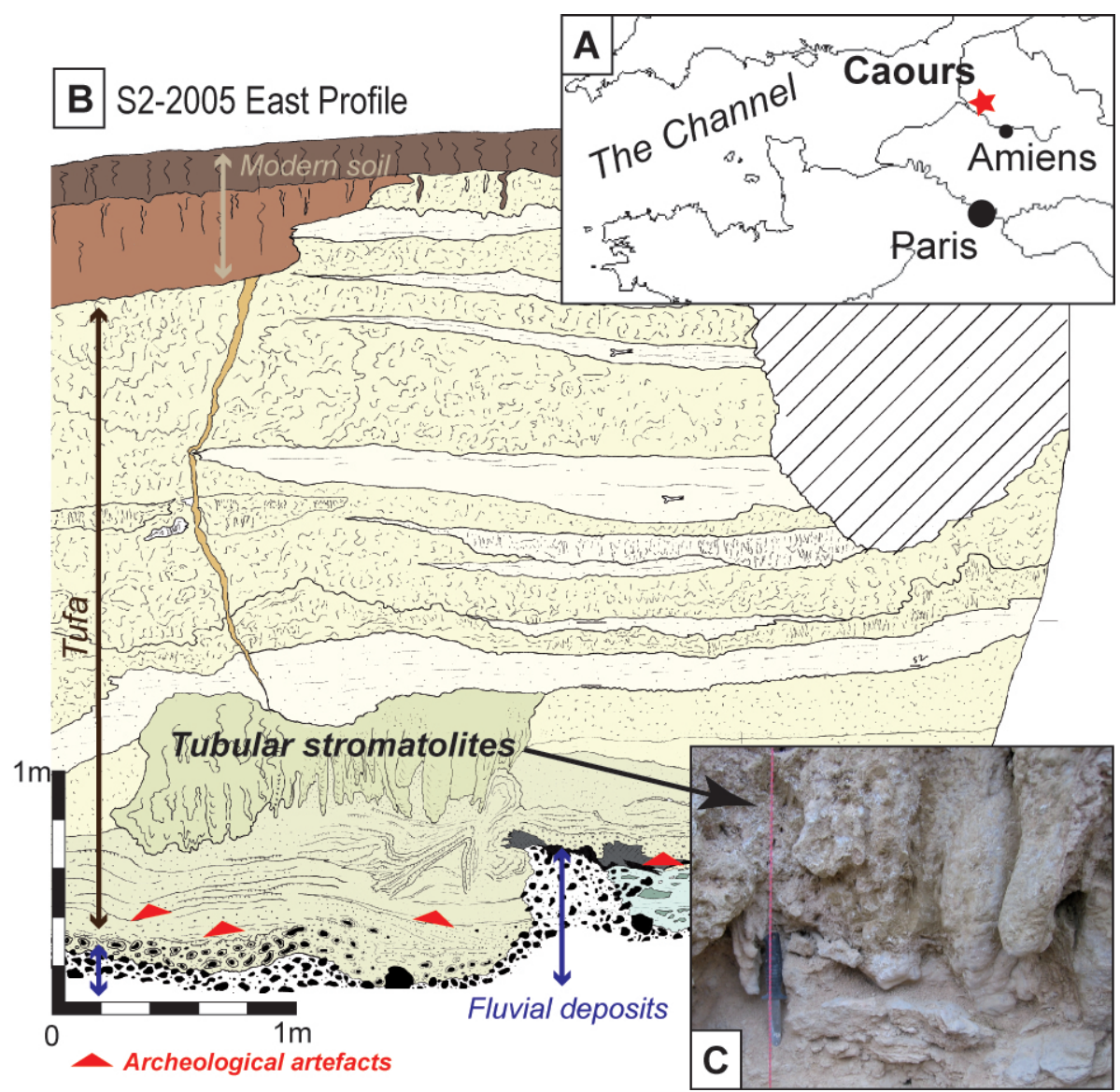

Fig. 1. (A) Location map of the Caours tufa; (B) east profile of the S2 excavation Sector in 2005 (Antoine et al., 2006; modified); (C) detail of the tubular facies at top of a localised channel.

\section{CPD}

9, 1657-1674, 2013

\section{Isotopes in tufa recording Eemian seasonal temperature}

J. Dabkowski et al.

\section{Title Page}

Abstract

Introduction

Conclusions

References

Tables

Figures
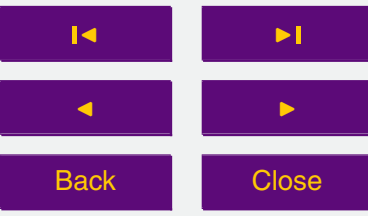

Back

Close

\section{Full Screen / Esc}

Printer-friendly Version

Interactive Discussion 


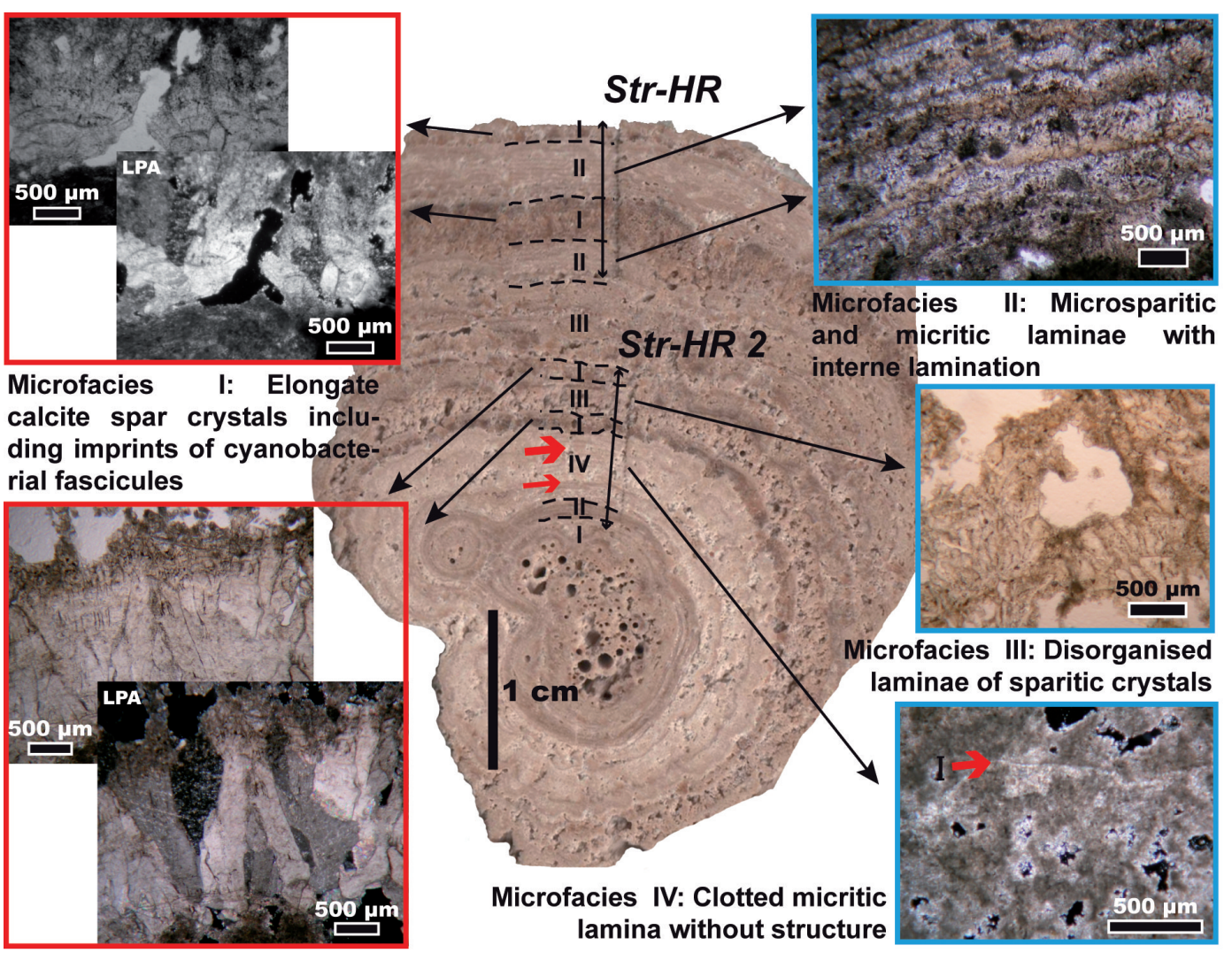

Fig. 2. Cross section of the Caours tubular stromatolite sampled for high-resolution analyses along Str-HR and Str-HR 2 series and microphotographies of facies observed in thin section (see text for detailed description).

\section{CPD}

9, 1657-1674, 2013

\section{Isotopes in tufa recording Eemian seasonal temperature \\ J. Dabkowski et al.}

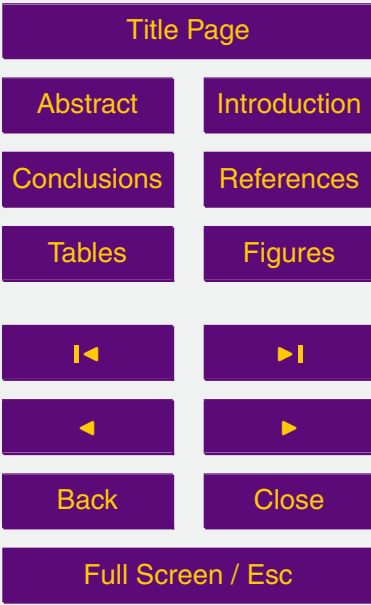

Printer-friendly Version

Interactive Discussion 


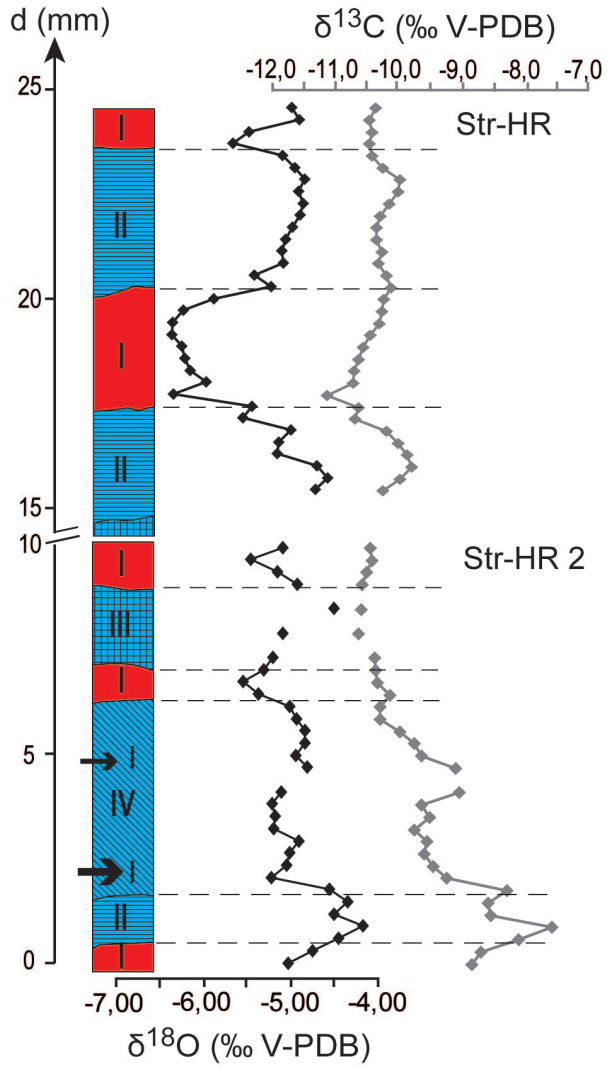

Fig. 3. High-resolution stable isotope results $\left(\delta^{18} \mathrm{O}\right.$ and $\left.\delta^{13} \mathrm{C}\right)$ from Caours stromatolite in accordance with distance (in $\mathrm{mm}$ ) from Str-HR 2 bottom and regarding to laminae microfacies presented in Fig. 2.

\section{CPD}

9, 1657-1674, 2013

\section{Isotopes in tufa recording Eemian seasonal temperature}

J. Dabkowski et al.

\section{Title Page}

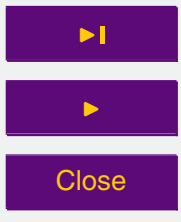

Back

Close

\section{Full Screen / Esc}

Printer-friendly Version

Interactive Discussion 


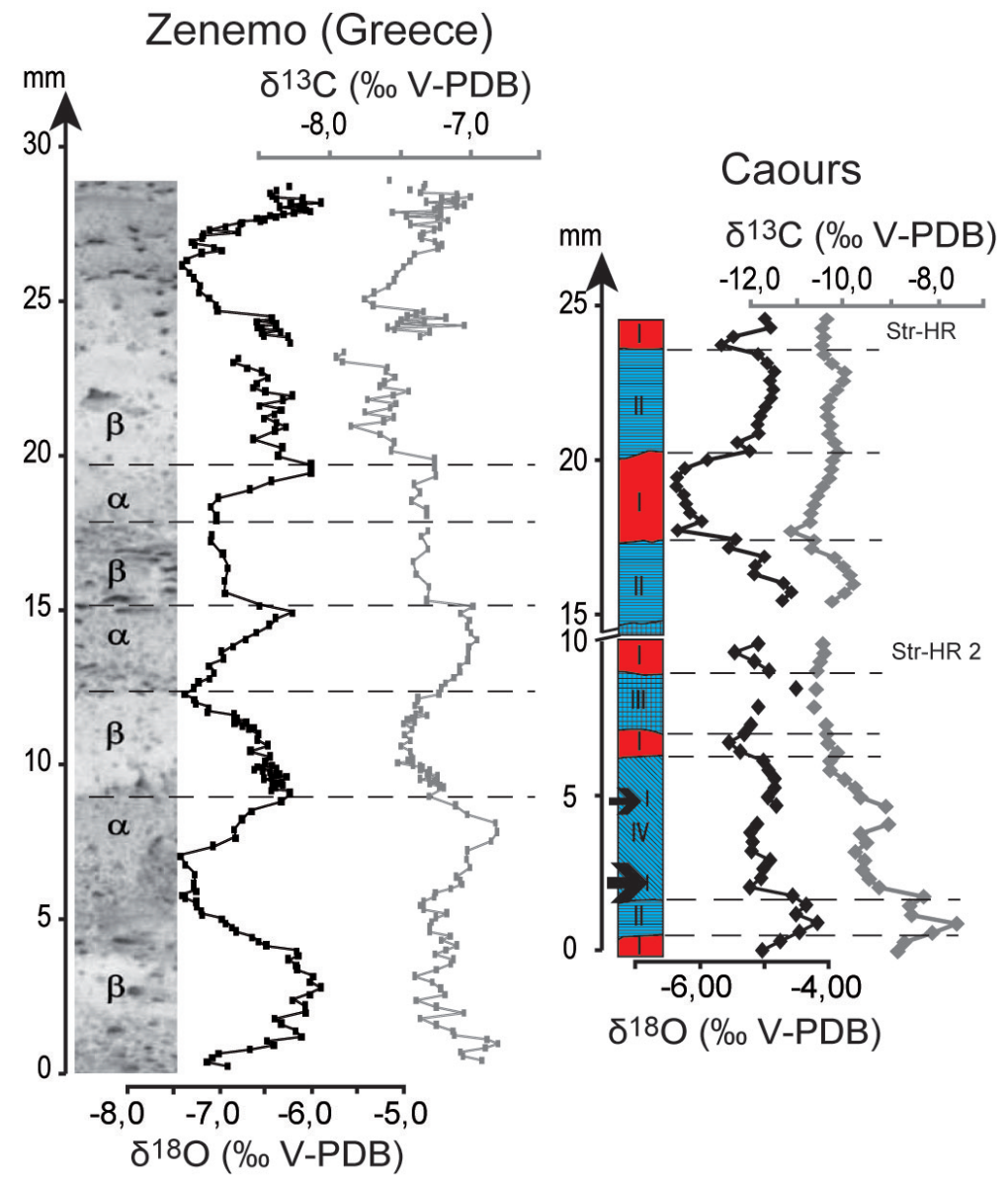

CPD

9, 1657-1674, 2013

\section{Isotopes in tufa recording Eemian seasonal temperature}

J. Dabkowski et al.

\section{Title Page}

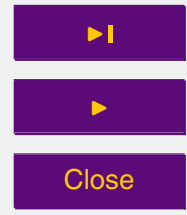

Back

Close

\section{Full Screen / Esc}

Printer-friendly Version

Fig. 4. Petrographical and high resolution calcite $\delta^{18} \mathrm{O}$ and $\delta^{13} \mathrm{C}$ data transect from Zemeno laminated tufa (Central Greece; Brasier at al., 2010) regarding to Caours data (this studies: Fig. 3). Depth scales are the same, horizontal dashed lines tie petrography with stable isotopes. 